Tribute

\title{
THE SOCIETY FOR SOCIALIST STUDIES LOSES A GREAT PIONEER
}

\author{
RADHIKA DESAI \\ University of Manitoba
}

Mel Watkins is gone. He was one of one or two handfuls of leading figures on the Canadian left whose work marked the country and its left deeply. The Society for Socialist Studies is proud to count him as one of its founding and, for many years, active members.

Mel took a lot of flack for being that thing - a "left nationalist" - so derided by the cosmopolitan, globalising left that took US imperialism for granted. Through it all, he stuck to his guns. I never met him, missing the one chance I had during this last trip to Winnipeg because I was travelling myself. However, we corresponded over our agreement on the importance of the state and the national economy in understanding capitalism, domestically and internationally, and advancing the cause of socialism. This does not imply - never did for Mel and does not for me nationalist chauvinism. Our understanding drew, inter alia, on Karl Marx, John Maynard Keynes and Karl Polanyi.

It is only on the foundation of a stable national economy that relations of true internationalism are possible, relations in which exploitation of other societies is neither attractive nor imperative. It's a bit that staple (no pun intended) of flight safety videos: always put on your own oxygen mask before helping another. If you don't, you will only endanger the safety of others. In the neoliberal age, Western countries have done the opposite. They have emaciated their productive economies to squeeze the last possible cent of profit, in the process their stretching supply lines thinly and tenuously across the globe. The financial and military strategies that necessarily accompanied this process regularly throw millions into war, economic crisis and deprivation and loss of habitat that drives ever more desperate migration.

Mel's emphasis on contesting US power went hand in hand with his commitment to the case of indigenous peoples. The two went hand in hand. Canada's subordinate alliance with Britain originated its fundamentally exploitative, expropriatory and oppressive relation with indigenous peoples. The relationship has only intensified as Canada has joined hands with the US. It will not disappear without creating an autonomous and socialist Canada. That is what Mel was about.

We have lost him at a time when his message is, if anything, more relevant than ever. Four decades of neoliberalism have created a productive structure of "just in time" production that makes no provision for any emergency, lacking a "just in case" principle that any decent society must have. The result is clear for all to see. We have before us the spectacle of Prime Ministers and Presidents of the foremost neoliberal powers trying to, and not always succeeding in, ordering 
domestic corporations to produce much needed medical equipment amid the greatest pandemic we have faced for more than a century. It only portends a far more horrific prospect: since four decades of globalizing neoliberalism have left us with a productive structure with little provision for contingencies, we are looking the possibility of the greatest Depression in the history of capitalism in the face with all that entails in terms of human suffering and social, ecological and spiritual dislocation.

I know from those who knew him that Mel was never the "I told you so" type, but history has certainly vindicated him. I hope he will have reason to smile from the blue yonder, at least of our memories, as be begin to take his message to heart, as we now must. 